Original Research Paper

\title{
The Influence of Trichoderma viride Cellulase Enzyme Concentration on Saccharification of Waste Paper Materials
}

\author{
${ }^{1}$ Khomotso M. P. Mokatse, ${ }^{2}$ M. Alfred Mogale and ${ }^{1}$ J. Pieter H. Van Wyk \\ ${ }^{1}$ Department of Pharmacology and Therapeutics, School of Medicine, \\ Sefako Makgatho Health Sciences University, Garankuwa, South Africa \\ ${ }^{2}$ Department of Biochemistry, School of Science and Technology, \\ Sefako Makgatho Health Sciences University, Garankuwa, South Africa
}

Article history

Received: 27-05-2021

Revised: 14-07-2021

Accepted: 15-07-2021

Corresponding Author:

J Pieter H van Wyk

Department of Pharmacology

and Therapeutics, School of

Medicine, Sefako Makgatho

Health Sciences University,

Garankuwa, South Africa

Email: pieter.vanwyk@smu.ac.za

\begin{abstract}
Enzymatic hydrolysis of lignocellulosic materials is one of the major steps in the commercialization process of converting cellulosic substrates into bio-products. The saccharification of lignocellulosic materials is usually achieved by a synergistic action of an enzyme mixture consisting of multiple cellulase enzymes such as endo- and exo-glucanase, cellobiohydrolase and $\beta$-glucosidase with different mode of actions. During the enzymatic hydrolysis of the paper materials the process started with an initial fast rate of hydrolysis followed by a rapid decrease of the rate towards the end of hydrolysis. Obtained from this investigation showed a direct relationship between sugar concentration released and increasing enzyme concentration used during the saccharification process. Most paper materials showed maximum sugar production at an enzyme concentration of 20 $\mathrm{mg} / \mathrm{mL}$ except filter paper that was maximally degraded at an enzyme concentration of $10 \mathrm{mg} / \mathrm{mL}$, brown envelope paper at an enzyme concentration of $10 \mathrm{mg} / \mathrm{mL}$ producing a sugar concentration of $13.22 \mathrm{mg} / \mathrm{mL}$ and resulted in a percentage saccharification of $18 \%$. Pick ' $n$ Pay paper yielded the lowest amount of sugar $(5.8 \mathrm{mg} / \mathrm{mL})$ when treated with a very high enzyme concentration of $30 \mathrm{mg} / \mathrm{mL}$ causing a percentage saccharification of $19 \%$. Although most paper materials were maximally bio-degraded with the same cellulase concentration the ratio of enzyme concentration to mass of paper material degraded is unique for each paper material.
\end{abstract}

Keywords: Waste Paper, Saccharification, T. viride Cellulase, Enzyme Concentration

\section{Introduction}

Currently biomass is the only renewable energy resource that can directly be converted into useful bio-products like bio-ethanol, bio-methane and bio-hydrogen (Du Preez, 2016). The largest biomass feedstock is lignocellulose, which is found globally in many forms such as corn stover, alfalfa, switchgrass, sawdust, paper mill residue, wood chips and forage grasses (Saini et al., 2015; Bilal et al., 2020). The conversion of lignocellulose into bio-products could relieve shortages of fuels and reduce dependence on fossil energy (Popp et al., 2014; Tan et al., 2020). In developed and developing countries municipal wastes have become a serious problem during the last century and therefore it is important to deal with the waste both for the comprehensive use of lignocellulosic resources and for the prevention of environmental pollution (Byadgi and Kalburgi, 2016).
Municipal solid waste mainly consists of food waste, wood, leaf, garden or yard waste, rubber, textile, leather, metals (ferrous metals), glass and paper boards (Byadgi and Kalburgi, 2016; Velvizhi et al., 2020; Chen, 2018; Hietala et al., 2018). About 35 to $40 \%$ of the municipal solid waste is made of paper (Byadgi et al., 2015). White paper consists of $85-99 \%$ cellulose, $0 \%$ hemicellulose and $0-15 \%$ lignin. Newspaper consists of $40-55 \%$ cellulose, $25-40 \%$ hemicellulose and $18-30 \%$ lignin (Sun and Cheng, 2002; Kaschuk and Frollini, 2018). The cellulose composition present in paper makes it a good feedstock for production of bio-products such as biochemicals, biofuels and bio-pharmaceuticals. Chemical and enzymatic methods are the most common techniques for hydrolyzing cellulose into sugars (Amezcua-Alliere et al., 2017; Lee and Yu, 2020; Siquera et al., 2020. Enzymatic hydrolysis has been used widely as an alternative to acid 
hydrolysis because the process is specific, can be performed under mild conditions ( $\mathrm{pH}$ around 5 and temperature less than $50^{\circ} \mathrm{C}$ ) with lower energy consumption and lower environmental impact (Lini et al., 2018). This method does not present corrosion problems and gives high yield of pure glucose with low formation of by-products that are favorable for the use in fermentation processes. The cellulolytic enzymes are either secreted into the substrate or attached to the cell wall of the microorganism when degrading cellulose (El-Ahmady et al., 2014).

The efficient use of enzymes depends on process variables such as temperature, $\mathrm{pH}$, reaction time, enzyme concentration, substrate concentration, intensity of agitation and presence of other chemical species that may inhibit or speed up their rates of reaction (Kaya et al., 2000; Maleki et al., 2020). The operating condition must be optimized due to the economic terms from the intense usage of enzyme, for the enzymatic process to be performed with high efficiency and optimization of the hydrolysis conditions is required (Kurchaska et al., 2018). The main factors that influence enzymatic hydrolysis can be divided into substrate features and enzyme-related factors. The use of high enzyme concentration generates high cellulose degradation costs however it also increases the sugar yield reduction at the same time. Hence, one of the best approaches to conquering the challenges is determining optimum factors like $\mathrm{pH}$, temperature and incubation time at low enzyme concentration such as observed by Tang et al. (2019) during the saccharification of pretreated rice straw at low cellulase loadings. Similar conclusions regarding enzyme loadings were made during the saccharification of sugarcane bagasse using celluclast and novozyme cellulase (Li et al., 2014) and degradation of cellulose from Bambusa bambos with Trichoderma reesei Rut C30 cellulase (Kuila et al., 2011). Waste paper is a major component of solid waste and it is classified as part of the organic section of solid waste which can be further categorized according to the type of paper present in solid waste such as newspaper, office paper and foolscap paper (Wang et al., 2011). This investigation reflects the influence of changing Trichoderma viride cellulase enzyme concentrations on the saccharification of waste paper materials as this is an important variable to optimizes such as incubation $\mathrm{pH}$ and temperature as well as the thermostability of the enzyme (Garcia et al., 2018).

\section{Materials and Methods}

\section{Research Design}

A fixed mass of different paper materials such as foolscap paper, Woolworths and Pick ' $n$ Pay advertising paper, office paper, filter paper, newspaper and brown envelope paper were saccharified with different concentrations of crude Trichoderma viride cellulase enzyme at an incubation temperature of $50^{\circ} \mathrm{C}$ and incubation temperature of $2 \mathrm{~h}$.
The amount of resulting sugars produced during each incubation period was determined to concluded the effect of cellulase concentration on the cellulase catalyzed bio-degradation of various paper materials.

\section{Waste Paper Materials}

Foolscap paper $(0.0350 \mathrm{~g})$, Woolworths paper $(0.0413 \mathrm{~g})$, brown envelope paper $(0.0658 \mathrm{~g})$, filter paper (0.0373 g), newspaper (0.0278 g), Pick ' $\mathrm{n}$ Pay paper $(0.0278 \mathrm{~g})$ and office paper $(0.0435 \mathrm{~g})$ were used as substrates for saccharification and determination of the influence of enzyme concentration on the bioconversion of these waste paper materials. Woolworths and Pick ' $n$ Pay papers were obtained from local retailers. Prior to enzymatic catalyzed biodegradation into fermentable sugars such as glucose these paper materials were prepared as circular discs with a diameter of $6.0 \mathrm{~mm}$ each.

\section{Cellulase Enzyme and Incubation with Waste Paper}

Crude Trichoderma viride cellulase $(0.1 \mathrm{~g})$ enzyme was weighed and dissolved in $50 \mathrm{~mL}$ of $0,05 \mathrm{M}$ Tris buffer $\mathrm{pH} 4.5$ and used as a stock solution for preparation of diluted enzyme solutions at different concentrations. These diluted cellulase enzyme solutions were prepared at concentrations of 2.5, 5.0, 7.5,10.0, 15.0, 20.0, 25.0, 30.0 and $35.0 \mathrm{mg} \cdot \mathrm{ml}^{-1}$. The cellulase enzyme-buffer solution was mixed with a magnetic stirrer until a homogenous solution was obtained. Aliquots $(100 \mu \mathrm{L})$ was transferred to a test tube filled with Tris buffer $(800 \mu \mathrm{L})$, methanol $(100 \mu \mathrm{L})$ and 20 pieces of paper material. This reaction mixture was incubated at $50^{\circ} \mathrm{C}$ for $2 \mathrm{~h}$.

\section{Sugar Analysis}

After the $2 \mathrm{~h}$ incubation period the various degraded waste paper materials mixtures were cooled to room temperature and mixed with the DNS reagent according to the method described by Miller (1959). The resulting mixtures were heated in a boiling water bath for a period of $10 \mathrm{~min}$, with the resulting colour intensity determined on a spectrophotometer (Shimadzu UV-1800) at $520 \mathrm{~nm}$. A sugar calibration curve was constructed using glucose standards ranging from 0.5 to $8.0 \mathrm{mg} / \mathrm{mL}$. This calibration curve was used to determine the concentration of the various sugar solutions obtained during the cellulase catalyzed degradation of the different waste paper materials.

\section{Calculation of Percentage Saccharification}

The percentage saccharification of the various paper materials was calculated as follows using the formula function of excel:

$$
\begin{aligned}
& \% \text { Saccharification }= \\
& \frac{\text { Reducing sugar }(\mathrm{mg} / \mathrm{ml})}{\text { Initial substrate concentration }(\mathrm{mg} / \mathrm{ml})} \times 0.9 \times 100
\end{aligned}
$$


The factor 0.90 was used to convert polysaccharide to monosaccharide accounting for water uptake during hydrolysis (Alrumman, 2016).

\section{Results and Discussion}

The production of value added products has been advocated as a sustainable option to tackle the problems associated with the rising of crude oil prices and environmental pollution caused by the consumption of fossil fuels and the production of increasing volumes of municipal solid wastes. The efficient conversion of cellulosic waste materials into bio-products is of utmost importance as this will assist in procedures to conserve the environment (De Bhowmick et al., 2017). Cellulose is the major structural component of higher plants and is amongst the most abundant organic substances on the earth and totals to an amount of almost $7 \times 10^{11}$ tons (Shweta, 2012). Cellulose contains highly ordered regions known as the crystalline component as well as less ordered regions known as amorphous sections which are more susceptible for cellulase catalyzed hydrolysis (Meng et al., 2016).

The glucose units in a cellulose structure are connected by means of $\beta$-1,4-glycosidic bonds which can be broken by the hydrolytic action of a multi-component enzyme system known as cellulase. Cellulase is composed of three types of enzymes namely exoglucanases $(\mathrm{CBH})$ which acts on the ends of the cellulose chain, releasing $\beta$-cellobioses, Endoglucanases (EG) which randomly attack the internal $O$-glycosidic bonds, producing glucan chains of different lengths and $\beta$-glycosidases acting specifically on the $\beta$-cellobiose disaccharides and produce glucose as a final product (Kuhas et al., 2011). Cellulases can be isolated from various fungal ( $\mathrm{Hu}$ et al., 2018) and bacterial sources (Datta et al., 2013) and these cellulase systems exhibit different relative saccharification rates when degrading cellulose due to the non-identical composition of cellulase components in cellulase enzyme systems obtained from various sources. Another factor that is also of paramount importance in determining the sugar formation from waste cellulose is the amount and availability of cellulose in an organic material such as waste paper. This variable together with the type of cellulase enzyme will to a great extent determine the effectiveness of the bioconversion of waste cellulose into fermentable sugars.

Figure 1 to 6 reflects the effect of different enzyme loadings from $T$. viride cellulase enzyme on the relative saccharification of various types of paper materials. A general observation during saccharification of all the paper materials was that the extent of sugar production was increased when increasing loads of cellulase were used during saccharification with maximum saccharification obtained with newspaper, Woolworths advertising paper, office paper and foolscap paper when these paper materials were exposed to an enzyme concentration of $20 \mathrm{mg} / \mathrm{mL}$.
Filter paper was maximally degraded with an enzyme concentration of $10 \mathrm{mg} / \mathrm{mL}$ (Fig. 5) while Pick 'n Pay advertising paper was optimally bio-converted at $30 \mathrm{mg} / \mathrm{mL}$ (Fig. 6). During the saccharification of newspaper (Fig. 1), the sugar yield increased significantly with the increase in enzyme concentration $(2,5-20 \mathrm{mg} / \mathrm{mL})$ used and when the enzyme concentration was increased above $20 \mathrm{mg} / \mathrm{mL}$ a decrease in saccharification was observed. The reason behind the decline in sugar production could be as a result of the enzymatic hydrolysis of cellulose that is a solid-liquid heterogeneous reaction. The enzyme molecule adsorbs to the cellulose's surface forming an unstable enzyme-substrate unit with the substrate further converted into reducing sugars. The adsorption quantity could also reach a maximum value when the enzyme binding to the substrate reach a saturated value producing a relative high saccharification yield, but the adsorption extent could not be increased when the cellulose is exposed to higher enzyme concentrations beyond a certain value (Kassanov et al., 2017). The highest relative percentage saccharification of newspaper was calculated at $23 \%$ when $20 \mathrm{mg} / \mathrm{mL}$ of enzyme dosage was added used for saccharification of newspaper. The percentage of newspaper saccharification follows the same tendency as observed with the sugar producing pattern produced when newspaper was degraded by increasing enzyme concentrations. When the highest sugar concentration of $7.2 \mathrm{mg} / \mathrm{mL}$ was produced newspaper was degraded at a percentage value of $23 \%$ while at the lowest sugar producing value of $3,5 \mathrm{mg} / \mathrm{mL}$ the percentage saccharification equals a value of $11.3 \%$. The increase in percentage saccharification from the lowest level of sugar production to the maximum amount of sugar released was 2.04 times. The average sugar released when degraded with all the enzyme concentration resulted in a value of $5.45 \mathrm{mg} / \mathrm{mL}$.

When Woolworths advertising paper (Fig. 2) was degraded with different enzyme dosages of $T$. viride cellulase a gradual increase in the sugar yield from $6.63 \mathrm{mg} / \mathrm{mL}$ to a maximum of $7.5 \mathrm{mg} / \mathrm{mL}$ at an enzyme concentration of $20 \mathrm{mg} / \mathrm{mL}$ was obtained. Increasing the enzyme concentration above $20 \mathrm{mg} / \mathrm{mL}$ caused a decline in the sugar yield with the lowest relative percentage saccharification calculated as $9.8 \%$ when $30 \mathrm{mg} / \mathrm{mL}$ enzyme concentration was loaded. When the highest sugar concentration was produced Woolworths paper was degraded at a percentage value of $16 \%$ while the percentage saccharification obtained when the lowest enzyme concentration was used proved to be 1,2 times less the maximum amount of sugar produced. The average sugar released when degraded with all the enzyme concentration resulted in a value of $6.31 \mathrm{mg} / \mathrm{mL}$.

The degradation of office paper as represented in Fig. 3 shows a maximum sugar yield at a concentration of $7.3 \mathrm{mg} / \mathrm{mL}$ at an enzyme concentration of $20 \mathrm{mg} / \mathrm{mL}$ used for the degradation process. At maximum sugar concentration yield a percentage saccharification of $15 \%$ 
was released with no higher sugar concentrations released when increasing enzyme concentrations were used to degrade this paper material. When the highest sugar concentration was produced office paper was degraded at a percentage value of $15 \%$ while the percentage saccharification obtained when the lowest enzyme concentration was used proved to be 1,7 times less the maximum amount of sugar produced. The average sugar concentration released during the degradation of office paper with all the enzyme concentration resulted in a value of $5.65 \mathrm{mg} / \mathrm{mL}$. Figure 4 , reflects the sugar producing profile when foolscap paper was treated with increasing concentrations of cellulase enzyme and the amount of sugar produced increased from $4.26 \mathrm{mg} / \mathrm{mL}$ when an enzyme concentration of $2.5 \mathrm{mg} / \mathrm{mL}$ was used during the saccharification to a maximum sugar yield of $7.1 \mathrm{mg} / \mathrm{mL}$ when an enzyme concentration of $20 \mathrm{mg} / \mathrm{mL}$ was used producing a maximum saccharification percentage of $18 \%$. Most papers showed maximal degradation at an enzyme concentration of $20 \mathrm{mg} / \mathrm{mL}$ and not higher and the reason for this could be due to the fact that high cellulase concentration may counteract the saccharification by increasing the rate of trans glycosylation reactions along with hydrodynamic instability (Alrumman, 2016). The maximum sugar concentration produced was 1,6 times higher than the sugar concentration released when saccharification of foolscap paper was degraded with the lowest enzyme concentration. The average sugar concentration released when foolscap paper was degraded with all the enzyme concentration resulted in a value of $5.7 \mathrm{mg} / \mathrm{mL}$.

Naturally filter paper has a high crystalline structure and is therefore very difficult to degrade with cellulase enzymes and during this investigation filter paper (Fig. 5) reached a maximum sugar yield of $6.73 \mathrm{mg} / \mathrm{mL}$ at an enzyme dosage of $10 \mathrm{mg} / \mathrm{mL}$ with a percentage saccharification of $16 \%$. The degradation of filter paper showed a 2,4 fold increase in saccharification from sugar released when the lowest enzyme concentration was used for the degradation process to the maximum concentration of sugar produced. The average sugar concentration released when filter paper was degraded with all the enzyme concentration resulted in a value of $5.1 \mathrm{mg} / \mathrm{mL}$. Brown envelope paper (Fig. 6) yielded the highest amount of sugar concentration of $13.22 \mathrm{mg} / \mathrm{mL}$ when exposed to at an enzyme concentration of $10 \mathrm{mg} / \mathrm{mL}$ resulting in a percentage saccharification of $18 \%$. Because of the relative high sugar yield produced when a low enzyme concentration was used during the saccharification process these results revealed that the cellulose in brown paper is more susceptible for cellulase catalyzed degradation than cellulose in other paper materials. The degradation of brown envelop paper showed a 1.3 fold increase in saccharification from sugar released when the lowest enzyme concentration was used for the degradation process to the maximum concentration of sugar produced. The average sugar concentration released when brown envelope paper was degraded with all the enzyme concentration resulted in a value of $11.8 \mathrm{mg} / \mathrm{mL}$.

The degradation pattern of Pick ' $n$ Pay paper is reflected in Fig. 7 showing this paper material reaching a maximum sugar concentration of $5.88 \mathrm{mg} / \mathrm{mL}$ at an incubated enzyme concentration of $30 \mathrm{mg} / \mathrm{mL}$. The highest percentage saccharification was $19 \%$ when $30 \mathrm{mg} / \mathrm{mL}$ enzyme concentration was used to degrade this paper. Of all the paper materials treated with the $T$. viride cellulase enzyme the Pick ' $n$ Pay paper required the highest enzyme concentration of $30 \mathrm{mg} / \mathrm{mL}$ for to reach-a maximum saccharification yield. It can be concluded due to the high cellulase concentration requirement that the cellulose of this materials offered a stronger resistance to hydrolytic action of the cellulase enzyme than cellulose present in the other paper materials. The amount of sugar released during maximum sugar production was 1,6 fold higher than the sugar concentration produced when the lowest enzyme concentration was used during the saccharification process. An average sugar concentration of $4.7 \mathrm{mg} / \mathrm{mL}$ was calculated when this material was exposed to all the enzyme concentrations.

Table 1 reflects the maximum sugar concentration released from different paper materials as well as the optimum percentage of saccharification when the various paper materials were degraded by the most effective cellulase concentration for each cellulose material. From the tabled information it can be concluded that the majority of the paper materials was optimum degraded at cellulase concentrations of $20 \mathrm{mg} / \mathrm{mL}$ with Pick ' $\mathrm{n}$ Pay paper maximally degraded with $T$. viride cellulase at an incubation concentration of $30 \mathrm{mg} / \mathrm{mL}$. The sugar concentration obtained when maximally concentrations were produced from the different paper materials varied between the lowest value of $5,8 \mathrm{mg} / \mathrm{mL}$ released from Pick ' $\mathrm{n}$ Pay paper to the highest value of $13,2 \mathrm{mg} / \mathrm{mL}$ produced during the degradation of brown envelope paper. The percentage saccharification of the various paper materials is however a more effective way to compare the relative susceptibility of the various paper materials for degradation by $T$. viride cellulase. The percentage saccharification varied between the lowest value of $15 \%$ obtained during degradation of office paper to the maximum degree of $23 \%$ produced when newspaper was saccharified by this enzyme. From the percentage saccharification it can be concluded that newspaper, although it produced not the most sugar, was the most effective in terms of relative saccharification. Although the least effective in terms of percentage saccharification office paper did not produced the lowest sugar concentration while Pick ' $n$ Pay paper which produced the lowest sugar concentration of $5,8 \mathrm{mg} / \mathrm{mL}$ was degraded at a magnitude of $19 \%$. Brown envelope paper which produced the highest sugar concentration is 
with filter paper the third most effective degraded material in terms of saccharification. Newspaper which was determined to be the most effective in terms of percentage saccharification was $153 \%$ more effective than office paper which showed the lowest degree of saccharification. Although much more effective than office paper, the amount of sugar produced by newspaper was less than the amount of sugar released from office paper.

The treatment of waste paper has been indicated in many post-utilized applications such as inductive feedstock for cellulase production (Dong et al., 2021), a lightweight cement mortar (Abed et al., 2021), mining of nanocellulose (Kumar et al., 2020) and biomethane production (Li et al., 2020). The sugar content of waste paper is however an important variable which would affect the extent of alternative products produced by using waste paper as feedstock. Such would be the relative yield of bioethanol (Darwesh et al., 2020), biobutanol (Farmanbordar et al., 2020), levulinic acid (Dutta et al., 2020) and bio-hydrogen (Jarunglumlerty et al., 2018) which bio-production is reliable to a certain to the amount of fermentable sugars release form the organic waste paper materials such as waste paper. When dependent on the amount of fermentable sugars to be released from waste paper and that would be utilized as feed-stock for further synthetic procedures the results obtained from this investigation would assist in concluding the relative amount of sugar to be released from various waste paper materials and would thus assist in the process of determining the yield of bio-products produce from organic waste materials such as waste paper.

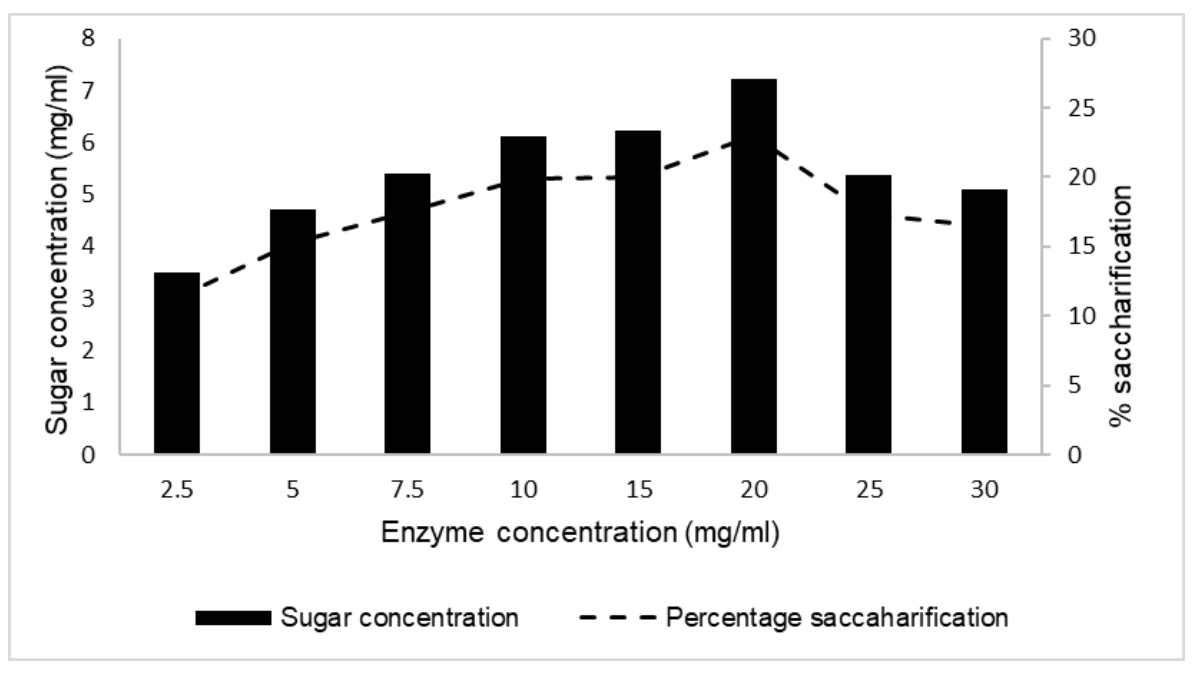

Fig. 1: Effect of enzyme concentration on saccharification of newspaper

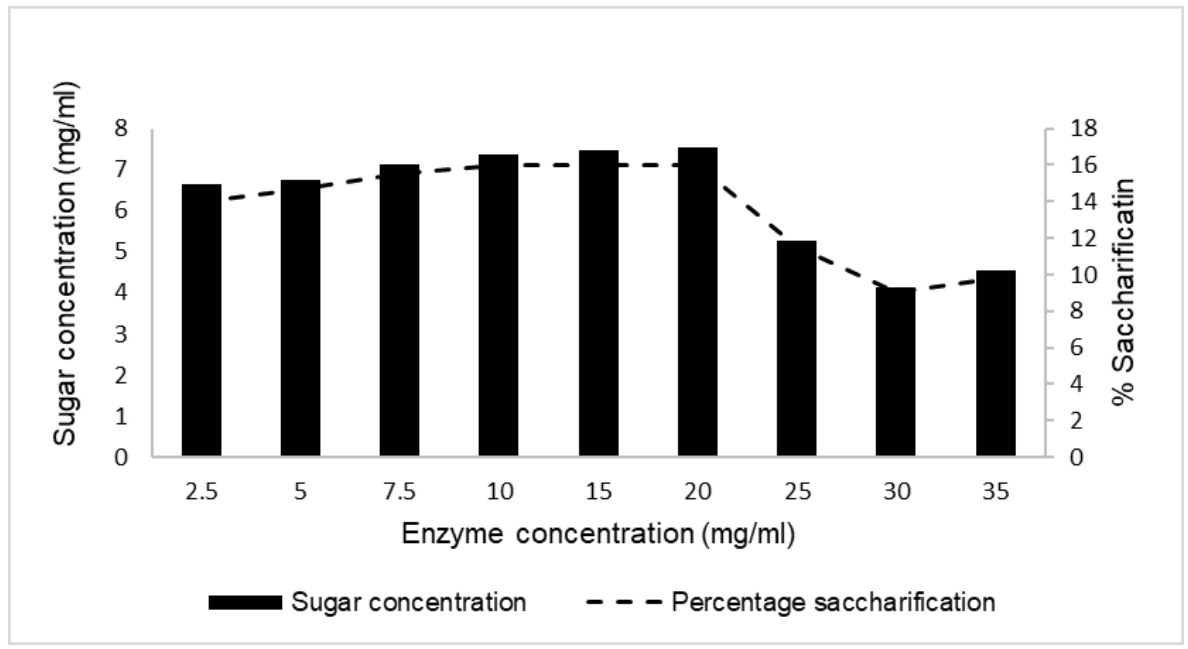

Fig. 2: Effect of enzyme concentration on saccharification of Woolworths advertising paper 


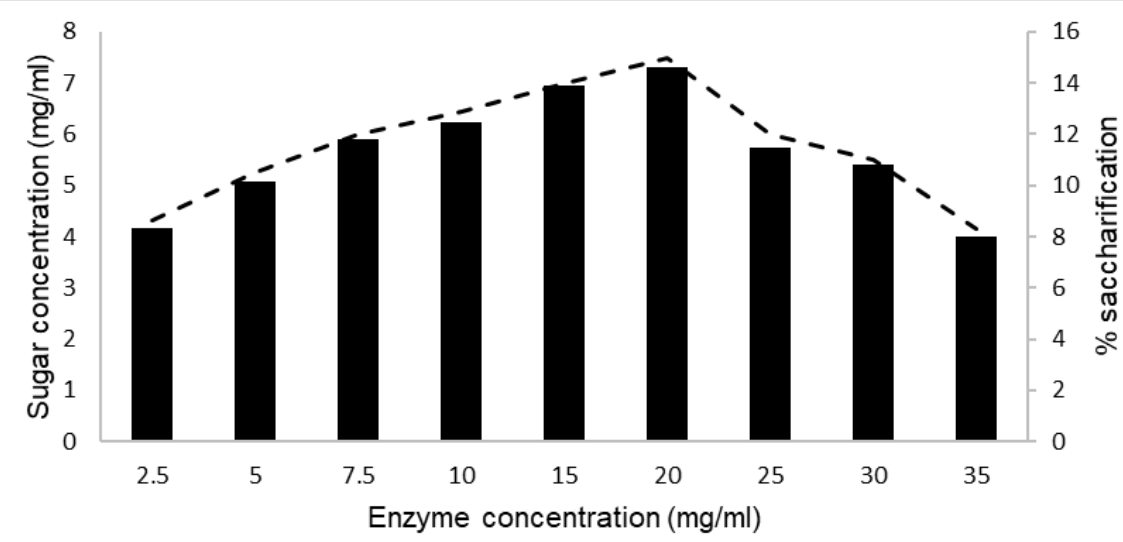

Sugar concentratiion _ - - Percentage saccharification

Fig. 3: Effect of enzyme concentration on saccharification of office paper

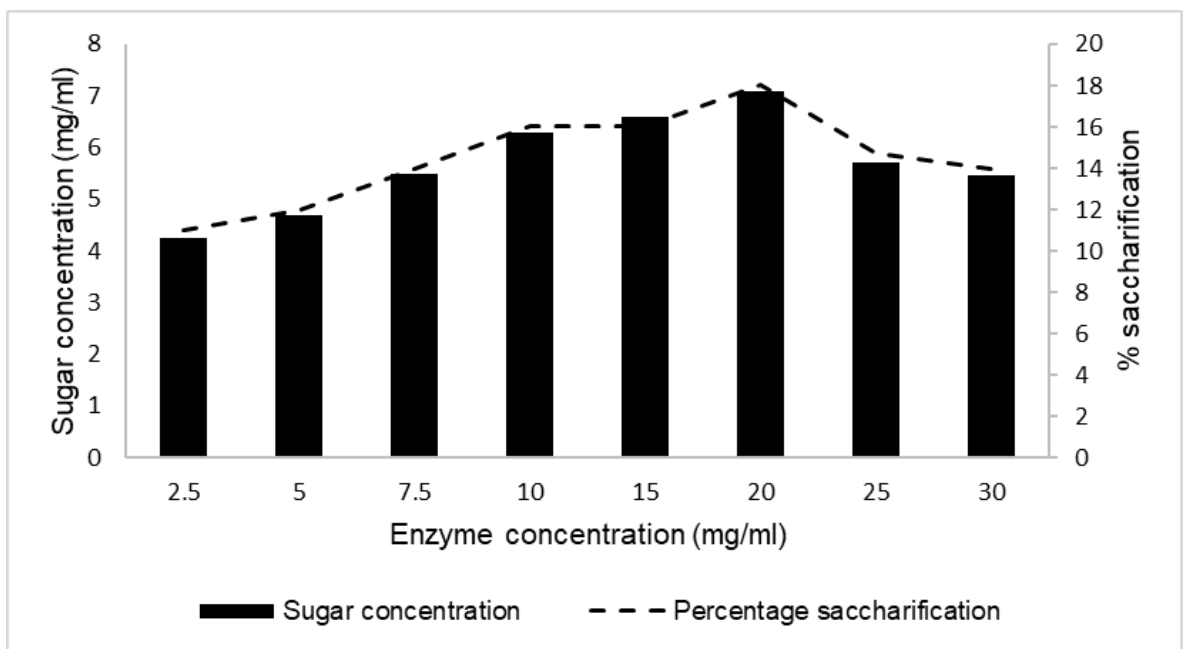

Fig. 4: Effect of enzyme concentration on saccharification of foolscap paper

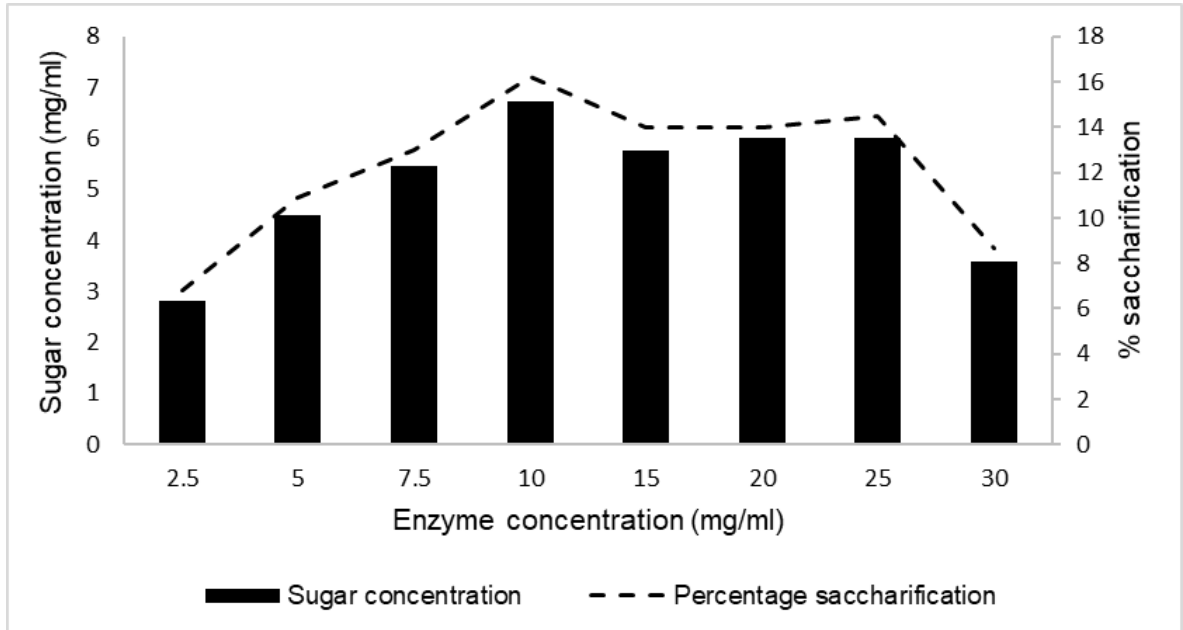

Fig. 5: Effect of enzyme concentration on saccharification of filter paper 


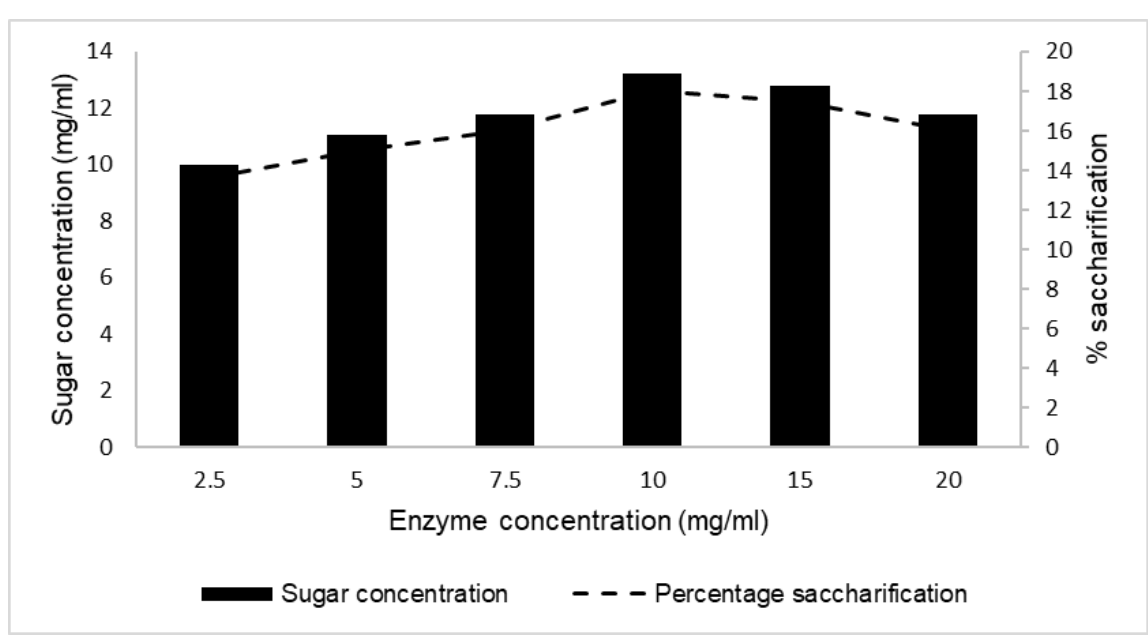

Fig. 6: Effect of enzyme concentration on saccharification of brown envelope paper

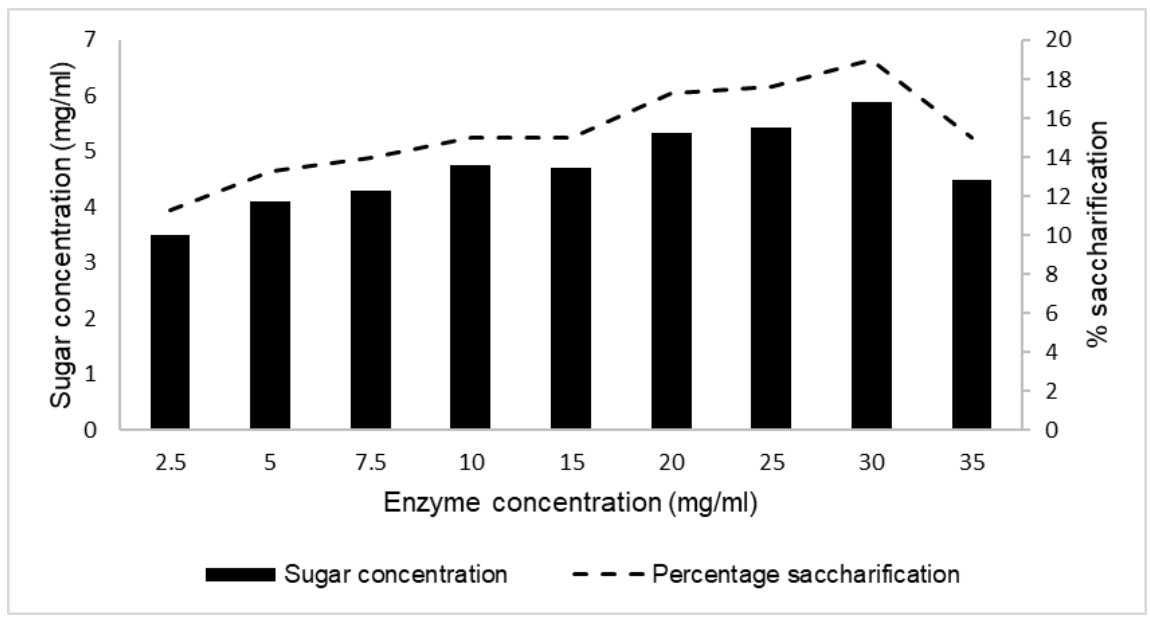

Fig. 7: Effect of enzyme concentration on saccharification of pick 'n pay advertising paper

Table 1: Maximum sugar concentration and percentage saccharification of various paper materials when treated with $T$. viride cellulase at a concentration producing optimum saccharification

\begin{tabular}{llcc}
\hline Paper material & $\begin{array}{l}\text { Enzyme concentration producing } \\
\text { maximum sugar concentration }(\mathrm{mg} / \mathrm{ml})\end{array}$ & $\begin{array}{l}\text { Maximum sugar } \\
\text { concentration }(\mathrm{mg} / \mathrm{ml})\end{array}$ & $\%$ Saccharification \\
\hline Newspaper & 20 & 7.2 & 23.0 \\
Wool worths paper & 20 & 7.5 & 16.0 \\
Office paper & 20 & 7.3 & 15.0 \\
Foolscap paper & 20 & 7.1 & 18.0 \\
Filter paper & 10 & 6.7 & 16.2 \\
Brown envelope paper & 10 & 13.2 & 18.0 \\
Pick 'n pay paper & 30 & 5.8 & 19.0 \\
\hline
\end{tabular}

\section{Conclusion}

Cellulose a structural component of organic waste materials such as used paper materials can be hydrolyzed into fermentable sugars with cellulase enzymes. From the study it has been concluded that different paper materials exhibit non-similar susceptibility for saccharification by $T$. viride cellulase. It is thus suggested that a specific cellulase - cellulose ratio should be determined to ensure the most effective degradation of each paper material into fermentable sugars such as glucose.

\section{Acknowledgement}

This research was funded by the Research Development Grant (RDG) of Sefako Makgatho Health Sciences University, South Africa. 


\section{Author's Contributions}

J. Pieter H. Van Wyk: Design, organize study, data analyses and write the manuscript.

M. Alfred Mogale: Design, organize and assist with writing of manuscript.

Khomotso M. P. Mokatse: Perform research activities, data analyses and construction of figures.

\section{Ethics}

This article is original and contains unpublished data. The authors declare no conflict of interest regarding publication of this paper. The authors declare no ethical issues will arise after the work has been published.

\section{References}

Abed, M. J., Khaleel, O. R., \& Fayyadh, M. M. (2021). Effect of aluminium sulphate Al2 (SO4) 3 treatment on paper waste as a fine aggregate partial replacement in lightweight cement mortar. Materials Today: Proceedings, 42, 1152-1159. doi.org/10.1016/j.matpr.2020.12.529

Alrumman, S. A. (2016). Enzymatic saccharification and fermentation of cellulosic date palm wastes to glucose and lactic acid. brazilian journal of microbiology, 47, 110-119. doi.org/10.1016/j.bjm.2015.11.015

Amezcua-Allieri, M. A., Sánchez Durán, T., \& Aburto, J. (2017). Study of chemical and enzymatic hydrolysis of cellulosic material to obtain fermentable sugars. Journal of Chemistry, 2017. doi.org/10.1155/2017/5680105

Bilal, M., Wang, Z., Cui, J., Ferreira, L. F. R., Bharagava, R. N., \& Iqbal, H. M. (2020). Environmental impact of lignocellulosic wastes and their effective exploitation as smart carriers-A drive towards greener and eco-friendlier biocatalytic systems. Science of The Total Environment, 722, 137903. doi.org/10.1016/j.scitotenv.2020.137903

Byadgi, S. A., \& Kalburgi, P. B. (2016). Production of bioethanol from waste newspaper Procedia Environmental Sciences, 35, 555-562. doi.org/10.1016/j.proenv.2016.07.040

Byadgi, S., Kalburgi, P. B., \& Yashoswi, M. (2015). Optimization of pretreatment and hydrolysis process in the production of bioethanol. The International Journal of Agricultural and Rural Development, 2, 1341-1345. doi.org/10.21090/IJAERD.0205187

Chen, Y. C. (2018). Effects of urbanization on municipal solid waste composition. Waste Management, 79, 828-836. doi.org/10.1016/j.wasman.2018.04.017

Darwesh, O. M., El-Maraghy, S. H., Abdel-Rahman, A., \& Zaghloul, R. A. (2020). Improvement of paper waste conversion to bioethanol using novel cellulose degrading fungal isolate. Fuel, 262, 116518. doi.org/10.1016/j.fuel.2019.116518
Datta, A., Gupta, B. L., \& Gupta, S. (2013). Optimization of cellulase production from bacterial isolated from soil. 985685. doi.org/10.5402/2013/985685

De Bhowmick, G., Sarmah, A. K., \& Sen, R. (2017). Lignocellulosic biorefinery as a model for sustainable development of biofuels and value added products. Bioresource Technology, 247, 1-10. doi.org/10.1016/j.biortech.2017.09.163

Dong, M., Wang, S., Xu, F., Xiao, G., \& Bai, J. (2021). Efficient utilization of waste paper as an inductive feedstock for simultaneous production of cellulase and xylanase by Trichoderma longiflorum. Journal of Cleaner Production. 308, 127287. doi.org/10.1016/j.jclepro.2021.127287

Du Preez, J.C. (2016). Biotechnology for Biofuels, 223. doi.org/10.1186/s13068-016-0637-4

Dutta, S., Yu, I. K. M., Tsang, D. C. W., Su, Z., Hu, C., Wu, K. C. W., Yip, A. C. K., Ok, Y. S., \& Poon, C. S. (2020). Influence of green sovent on levulinic acid production from lignocellulosic paper waste. Bioresource Technology, 298, 122544. doi.org/10.1016/j.biortech.2019.122544

El-Ahmady, N., El-Nagga, S.D., \& Khalil, A. (2014). Bioethanol production from lignocellulosic feedstocks based on enzymatic hydrolysis: Current Status and Recent Developments. Biotechnology, 13, 1-21. doi.org/10.3923/biotech.2014.1.21

Farmanbordar, S., Amiri, H., \& Karimi, K. (2020). Synergy of municipal solid waste co-processing with lignocellulosic waste for improved biobutanol production. 118, 45-54. doi.org/10.1016/j.wasman.2020.07.053

Garcia, N. F. L., da Silva Santos, F. R., Bocchini, D. A., da Paz, M. F., Fonseca, G. G., \& Leite, R. S. R. (2018). Catalytic properties of cellulases and hemicellulases produced by Lichtheimia ramosa: potential for sugarcane bagasse saccharification. Industrial Crops and Products, 122, 49-56. doi.org/10.1016/j.indcrop.2018.05.049

Hietala, M., Varrio, K., Berglund, L., Soini, K., \& Oksman, K. (2018). Potential of municipal solid waste paper as raw material for production of cellulose nanofibers. Waste Management. 80, 319-326. doi.org/10.1016/j.wasman.2018.09.033

Hu, Y., Du, C., Pensupa, N., \& Lin, C. S. K. (2018). Optimization of fungal cellulase production from textile waste using experimental design. Process Safety and Environmental Protection, 118, 133-142. doi.org/10.1016/j.psep.2018.06.009

Jarunglumlert, T., Prommuak, C., Putmai, N., \& Pravasant, P. (2018). Scaling-up bio-hydrogen production from food waste: Feasibilities and challenges. International Journal of Hydrogen Energy. 43(2), 634-648. doi.org/10.1016/j.ijhydene.2017.10.013 
Kaschuk, J. J., \& Frollini, E. (2018). Effects of average weight, crystallinity and hemicelluloses content on the enzymatic hydrolysis of sisal pulp, filter paper and microcrystalline cellulose. Industrial Crops and Products. 115, 280-289. doi.org/10.1016/j.indcrop.2018.02.011

Kassanov, B., Wang, J., Fu, Y., \& Chung, J. (2017). Cellulose enzymatic saccharification and preparation of 5-hydroxymethylfurfural based on bamboo hydrolysis reside separation in ionic liquids. RSC Advances, 7, 30755-30762. doi.org/10.1039/C7RA05020H

Kaya, F., Heitman, J.A. \& Thomas, G. (2000). Influence of lignin and its degradation products on enzymatic hydrolysis of xylan. Journal of Biotechnology, 80, 241 - 247.

Kuhas, R. C., Gupta, R., \& Singh, A. (2011). Cellulases and their Industrial Applications. Enzyme Research, 280696. doi.org/10.4061/2011/280696

Kuila, A., Mainak, M., Tuli, D. K., \& Banerjee, R. (2011). Accessibility of enzymatically delignifed Bambusa bambos for efficient hydrolysis at minimum cellulase loading: An optimization study. Enzyme Research, 805795. doi.org/10.4061/2011/805795

Kumar, V., Pathak, P. \& Bhardwaj, N. K. (2020). Waste paper: An underutilized but promising source for nanocellulose mining. Waste Management, 102, $281-303$. https://doi.org/10.1016/j.wasman.2019.10.041

Kurchaska, K., Rybaracyk, P., Holowacz, I., Lukajtis, R., Glinka, M., \& Kaminski, M. (2018). Pretreatment of lignocellulosic materials as substrates for fermentation processes. Molecules, 23, 1-32. doi.org/10.3390/molecules23112937

Lee, I., \& Ty, J. H. (2020). The production of fermentable sugars and bioethanol from acacian wood by optimizing dilute sulfuric acid pretreatment and post-treatment. Fuel, 275, 117943. doi.org/10.1016/j.fuel.2020.117943

Li, J., Zhou. P., Liu, H., Wu, K., Kang, X., Gong, Y., Xiao, W., Lin, J., \& Liu, Z. (2014). A comparison of fermentable strategies for cellulosic ethanol production from $\mathrm{NaOH}$-soaked sugar cane bagasse at high solid loading with decreased cellulase loading. Industrial Crops and Products, 62, 446-452. doi.org/10.1016/j.indcrop.2014.09.007

Lini, F. Z., Widjaja, T., Hendrianie, N., Alyway, A., Nurkhamida, S., \& Tansil, Y. (2018). The effect of organosolv pretreatment on optimization of hydrolysis process to produce the reducing sugar. MATEC Web Conferences., 154, 1-7. doi.org/10.1051/matecconf/201815401022

Maleki, M., Sharaki, M. F., Kavousi, K., Ahriaeenejad, S., \& Salekdeh, G. H. (2020). A novel cellulase cocktail enhances lignocellulosic bioconversion enhances in a broad range of $\mathrm{pH}$. International Journal of Biological Macromolecules, 154, 349-360.

doi.org/10.1016/j.ijbiomac.2020.03.100
Meng, X., Yoo, C. G., Li, M., \& Ragaukas, A. J. (2016). Physicichemical structural changes of cellulosic substrates during enzymatic saccharification. 2016. Journal of Applied Biotechnology and Bioengineering, 1, 87-94. doi.org/10.15406/jabb.2016.01.00015

Miller, G. L. (1959). Use of dinitrosalicylic acid reagent for determination of reducing sugar. Analytical Chemistry, 31, 426-428. doi.org/10.1021/ac60147a030

Popp, J., Lakner, Z., Harangi-Rakos, M., \& Fari, M. (2014). The effect of bioenergy and expansion: Food, energy and environment. Renewable and Sustainable Energy, 32, 559-578. doi.org/10.1016/j.rser.2014.01.056

Saini, J. K., Saini, R., \& Tewari, L. (2015). Lignocellulosic agriculture wastes as biomass feedstocks for secondgeneration bioethanol production: Concepts and recent developments. 3 Biotechnology, 5, 337-353. doi.org/10.1007/s13205-014-0246-5

Shweta, A. (2012). Cellulases of bacterial origin and their applications: A review. International Journal of Science and Research, 358 (10): 1652-1655.

Siquera, J. G. W., Rodriques, C., Vandenberghe, L. P., Woiciechow, A. H., \& Socca, C. R. (2020). Current advances in on-site cellulase biomass conversion to biofuels: A review. Biomass and Bioenergy, 132, 105419. doi.org/10.1016/j.biombioe. 2019.105419

Sun, Y., \& Cheng, J. (2002). Hydrolysis of lignocellulosic materials for ethanol production: a review. Bioresource technology, 83(1), 1-11. doi.org/10.1016/s0960-8524(01)00212-7

Tan, Y. T., Chua, A. S. M., \& Ngoh, G. C., (2020). Deep eutectic solvent for lignocellulosic biomass fractionating and the subsequent conversion to biobased products - A review. Bioresource Technology, 297, 122522. doi.org/10.1016/j.biortech.2019.122522

Tang, S., Dong, Q., Fang, Z., Cong, W., \& Miao, Z. (2019). High-concentrated substrate enzymatic hydrolysis pf pretreated rice straw with glycerol and aluminium chloride at low cellulase loadings. Bioresource Technology, 295, 122164. doi.org/10.1016/j.biortech.2019.122164

Velvizhi, G., Shanthakumar, S., Das, B., Pugazhendi, A. Priya, S., Ashok, B., Nanthagopal, K., Vignesh, R., \& Karthick, C. (2020). Biodegradable and nonbiodegradable fraction of municipal solid waste for multifaceted applications through a closed loop integrated refinery platform: Paving a path towards circular economy. Science of the Total Environment, 731, 138049. doi.org/10.1016/j.scitotenv.2020.138049

Wang, W., Kang, L., \& Wei, H. (2011). Study on the decreased sugar yield in enzymaticn hydrolysis of cellulosic substrate at high solid loading. Applied Biochemistry and Biotechnology, 164, 1139-1149. doi.org/10.1007/s12010-011-9200-8 